Modern Asian Studies 37, 3 (2003), pp. 653-682. (C) 2003 Cambridge University Press DOI: 10.1017/S0026749X03003056 Printed in the United Kingdom

\title{
Tuberculosis, Housing and the Colonial State: Hong Kong, I900-1950
}

MARGARET JONES

Wellcome Unit for the History of Medicine

University of Oxford

\section{Introduction}

As Tak-Wing Ngo has argued, the 'dominant' view of colonial rule in Hong Kong is one of a state which governed through 'a deliberate policy of indirect rule-a combination of economic laissez-faire and political non-intervention'. ${ }^{1}$ It depicts a government which was disengaged from the population, preferring to see the colony as a trading opportunity, whilst leaving the condition of the peoples it held sway over to the philanthropy and humanitarianism of the colony's Chinese elites. ${ }^{2}$ This view of British rule was even supported by the primary representative of the imperial state when Sir David Trench admitted in 1970 that social policy, in the sense of responding to the needs of the populace, only began in the colony in $1953 .{ }^{3}$ But as Tak-Wing Ngo has argued, these 'established narratives' of Hong Kong's colonial history need to be reassessed and a more nuanced approach adopted to reveal the complexity of even Hong Kong's seemingly simple 'colonial state-society' relations. ${ }^{4}$

Sir David Trench highlighted 1953 as the year when social policy came to Hong Kong for two reasons. Firstly, the Government had begun to accept by the early $195^{\circ}$ os that the refugees who flooded

I would like to thank Paul Wilding and Ian Gough and an anonymous referee for their comments on an earlier draft.

1 Tak-Wing Ngo, 'Colonialism on Hong Kong Revisited', in Tak-Wing Ngo (ed.), Hong Kong's History: State and Society under Colonial Rule (London: Routledge, 1999), $1-12,3$.

2 See, for example, C. Jones, Promoting Prosperity: The Hong Kong Way of Social Policy (Hong Kong: Chinese University Press, 1990), $115^{-5}$.

${ }^{3}$ P. Hodge, 'Social Policy: An Historical Perspective as Seen in Colonial Policy', Journal of Oriental Studies, 9:4 (1973), 207-19, 207. Sir David Trench served as Governor from 1964 to 1971 .

${ }^{4}$ Ngo, 'Colonialism on Hong Kong Revisited', 3.

oo26-749X/o3/\$7.50+\$0.10 
into the colony from mainland China after the success of Mao Tsedung were not going to return to China at some point in the future. Before the Second World War it had always been the official view that the Chinese who came to Hong Kong were itinerant workers who need not be regarded in the main as residents. Thus they were not the responsibility of the government. This realization that the hitherto shifting population was in fact now permanent, it is argued, led to the recognition that social services for all had to be provided by the state.

The precipitating event which cemented this change of attitude was the Shek Kip Mei fire on Christmas night 1953 which left $5^{\mathrm{O}, \mathrm{OOO}}$ people homeless. In the light of the disaster the government acknowledged that, after feeding and clothing the homeless, the third essential task was to 'house those who have been rendered homeless'. According to Lee Ming Kwan this 'was the origin of the Government's massive resettlement programme and the beginning of its public housing policy'. ${ }^{5}$ In this he echoes many other commentators on this issue who argue that the fire proved to be the turning point in the development of an interventionist colonial state with state subsidized housing as the vanguard. ${ }^{6}$ Prompted by various motives, such as the desire to reduce the cost of looking after the homeless, the need to diminish the risk of future fires, to free valuable land for economic development and to ensure an accessible labour supply for such development, the government embarked on a public housing policy and set up a Government Resettlement Department in 1954 to oversee the construction of cheap and basic housing for the labouring classes. In the 1970 s these imperatives were buttressed by a political crisis within the colony (a spill over from the cultural revolution) which led the government to defend itself in 1972 through the implementation of a ten-year plan with the eventual aim of housing 1.8 million people. ${ }^{7}$ This commitment to the provision of public housing is still a prominent feature of state

${ }^{5}$ Lee Ming Kwan, 'Hong Kong Identity-Past and Present', in Wong Siu-lun and Toyojiro Maruya (eds), Hong Kong Economy and Society: Challenges in the New Era (Hong Kong: Centre of Asian Studies, University of Hong Kong, 1998), 153-75, $15^{6 .}$

${ }^{6}$ See especially, D. W. Drakakis-Smith, Housing Policy in Metropolitan Hong Kong (Hong Kong: Centre of Asian Studies, 1973) and E. Castells, L. Goh and R. Kwok, The ShekKipMei Syndrome (London: Pion, 1990).

${ }^{7}$ Kwong-leung Tang, Colonial State and Social Policy: Social Welfare Development in Hong Kong, 1942-1997 (Lanham: University Press of America, 1998), 51, 60-3. 
activity in Hong Kong at the present time where it is estimated that

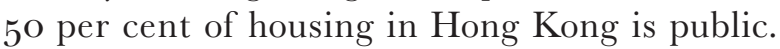

The provision of public housing in Hong Kong has served to exemplify a change of direction for the colonial state moving it from a non-interventionist state to one which engages and takes responsibility for the well being of its citizens. It started after the Second World War when political and social problems came together to prompt government action. The emphasis in these accounts is on fundamental change rather than continuity. As Catherine Jones has asserted, 'housing provision ... was one line in government activity decidedly not carried over from before the war' and furthermore that it was not an 'objective those back in charge from 1945 had any intention of pursuing'. ${ }^{8}$ M. Castells, L. Goh and R. Y-W Kwok also argue that 'public housing in Hong Kong started as a Christmas tale'. ${ }^{9}$ This paper will argue that this emphasis on a turning point is not sustainable in its entirety, and that an exploration of the government's attitude and policies towards the housing of its populace in the interwar years shows more continuity than hitherto acknowledged. The occupation of the Japanese renders this continuity obscure but it is there if sought.

Although the government took no direct action before 1941, it is possible that this was as much to do with the contingencies of history as it was with the nature of the colonial state. In the late 1930 s the Hong Kong government considered the possibility of providing housing for the labouring classes, on the lines of public provision in the United Kingdom. In this period it was a severe public health problem, the scourge of tuberculosis, which potentially drew it to this radical departure. As Catherine Jones has acknowledged in relation to the plague epidemic of the late 1890 s, 'the cumulative threat of epidemic disease ... being no respecter of persons, was over the longer term to prove a force for reform'. ${ }^{10}$

This study therefore explores two main questions. Firstly, to what extent can it be argued that there was continuity between preSecond World War and post-Second World War government housing policy. Secondly what does this tell us about the nature of the colonial state of Hong Kong? These questions will be explored through an examination of government responses to tuberculosis in Hong Kong in the period $1920-195^{\circ}$.

\footnotetext{
8 Jones, Promoting Prosperity, 181.

9 Castells, Goh and Kwok, The ShekKipMei Syndrome, 18.

${ }^{10}$ Jones, Promoting Prosperity, 125.
} 
The sources used are the official sources held at the Public Record Office, Kew. They include the annual reports of the medical directors, the correspondence between the Colonial Office (CO) and the Governor, and the minutes of officials at the CO. Reference will also be made to the memoirs of Sir Percy Selwyn-Clarke, who was the director of the medical services from 1938 until the occupation. These are held at the Rhodes House Collection at Oxford.

There are six sections. The first examines Hong Kong's governmental system in the interwar period in order to contextualize this discussion and illuminate the nature of this particular colonial state. The second section presents a health profile of the colony's population compiled from the medical reports. The third section explores the problem of tuberculosis in the colony and its relationship with poor housing conditions. The fourth and fifth examine the government's response to this public health problem and analyse the extent to which it contemplated moving from a minimal regulatory role to a more interventionist one in housing in order to alleviate it. The concluding remarks will return to the two main questions outlined above.

\section{Hong Kong's Colonial State}

In order to understand the policy-making process in Hong Kong it is first necessary to explore the distribution of power in the colony. Hong Kong was a crown colony theoretically governed from London through the crown representative in the person of the Governor, who was assisted by Executive and Legislative Councils composed of official and unofficial members. The Executive Council, composed only of officials and meeting in private, was mainly concerned with routine business, such as approving draft bills and confirming administrative decisions. The Legislative Council was the law-making body in the sense that it debated and approved all bills and the annual estimates. Whilst the Governor was expected to pay deference to views expressed therein, he could always expect a majority as official members were obliged to support him. He was the supreme authority, appointed directly by the crown. He was responsible for administration and he alone could initiate legislation. Thus the Governor had 'virtually complete control over both executive and legislative 
branches of government'; his authority checked only by the Secretary of State for the Colonies. ${ }^{11}$

In Hong Kong the basic powers of the Governor and the Councils remained in essence unaltered until 1940 and beyond. The minor changes in constitutional arrangements which occurred made almost no difference to the way British rule operated in the period. Changes were mainly limited to tinkering with the composition of the Legislative and Executive Councils. At the end of the nineteenth century two nominated unofficial members were added to the Executive Council. One other was added in 1920. No Chinese sat on the Executive Council until Sir Shou-son Chow was nominated by Cecil Clementi, the Governor, in 1926. The Executive Council also consisted of the General Officer Commanding British Forces and five officials, with the Chinese before 1926 being represented by the Secretary for Chinese Affairs (who was European). Similarly there were few changes to the Legislative Council. Four new members were added to the existing thirteen members in 1929-two official and two unofficial members which left the balance unaltered. Officials on the Legislative Council included the Colonial Secretary, the Attorney General and the Treasurer. The Director of Medical and Sanitary Services did not gain a seat until the increase in membership in 1929. There were four European unofficial members throughout the period-two were nominated by the Governor, one was elected by the Justices of the Peace and one chosen by the General Chamber of Commerce. Up to 1929 there were two Chinese on the Council and thereafter, three. ${ }^{12}$

According to Miners, service on the Legislative Council in Hong Kong was a far from onerous burden. It met on average about eighteen times a year; bills usually went through without much debate; apparently with disagreements being resolved in private beforehand. The Chinese unofficials were quiescent on the Council, seldom taking a separate stance from the European officials until the 1930 s when they began to play a more active role. Miners argued that this was due to their preference for channelling the views and interests of the Chinese community through the District Watch Committee, the organization of the leading Chinese in the community which

${ }^{11}$ N. Miners, Hong Kong under Imperial Rule, I9I 2-I94 I (Hong Kong: Oxford University Press, 1987), 43.

${ }^{12}$ Ibid., 59-6o. 
met under the auspices of the Secretary for Chinese Affairs. ${ }^{13}$ The explanation for this lack of involvement and hence arguably the absence of political change is variously attributed to the transient nature of Hong Kong's population, the preference of the Chinese for creating their own associations and a general preoccupation with commercial rather than political affairs. ${ }^{14}$

In 1898 the British Government leased the New Territories from the Chinese. This might have been expected to lead to changes as the population here was settled rather than migrant. However, the general policy, according to Charles Collins, was to interfere as little as possible and to adapt existing methods of administration to the new conditions. ${ }^{15}$ District Officers administered the territories sometimes, as elsewhere in the empire, with the co-operation of village elders. This form of indirect rule whereby rural leaders were the 'middlemen between the colonial administrative structure and the villagers' continued until the urbanization of the New Territories in the $195^{\text {os. }}{ }^{16}$

Civil servants for the Asian colonies (Hong Kong, Malay States and Ceylon) were recruited into what was known as the Eastern Cadet Service. This dated back to $185^{6}$ when the Colonial Office decided that all candidates for service in the eastern colonies should qualify by the same open competitive examination as those candidates for the Home Civil Service and the Indian Civil Service. Those with the best results usually chose the latter two and the rest opted for Ceylon, Hong Kong and Malaya in that order. ${ }^{17}$ This system of recruitment remained until the 1931 Warren Fisher Report on the reform of the civil service, which resulted in a unified Colonial Administrative Service with recruitment by interview and an investigation into the candidate's background and character. ${ }^{18}$ From 1904 all candidates for Eastern Cadetships in Hong Kong and Malaya had

13 Ibid., 54-5, 59-62.

${ }^{14}$ Hodge, 'Social policy: An Historical Perspective', p. 208; H. J. Lethbridge, 'A Chinese Association in Hong Kong: the Tung Wah', Contributions to Asian Studies, 2:1 (1972); Jones, Promoting Prosperity, 55-64, 123-25.

C. Collins, Public Administration in Hong Kong (London: Royal Institute of International Affairs, 1952), 138.

${ }^{16}$ S. W. K. Chiu and Ho-fung Hung, 'State Building and Rural Stability' in TakWing Ngo (ed.), Hong Kong's History, 75 .

${ }_{17}$ Miners, Hong Kong under Imperial Rule, 85 ; R. Heussler, British Rule in Malaya. The Malayan Civil Service and its Predecessors I867-1942 (Oxford: Oxford University Press, 1981), $4^{6-47 .}$

${ }^{18}$ See R. Furse, Acuparius: Recollections of a Returning Officer (London: Oxford University Press, 1962), 219-40. 
to be of pure European descent on both sides of the family. In Hong Kong no opportunities existed in this period for Chinese to enter the Civil Service. ${ }^{19}$

What has been described is thus a virtually European-dominated government. Furthermore it was not mitigated, as it was in the other Asian colonies and India for example, by any form of an indigenous elected local authority. A Sanitary Board was set up in 1887 , following Osbert Chadwick's report into the sanitary conditions of the town. This mainly consisted at the outset of official members, with six additional members, four to be nominated by the Governor (two of these were Chinese) and two elected on a very limited franchise of ratepayers. Pressure to turn this into a municipal council, on the same lines as those of Singapore and other colonial cities in Asia, was resisted by successive Governors. ${ }^{20}$ The Sanitary Board continued to be the only local authority in Hong Kong until the reforms of the mid 1930s. The Urban Council set up in 1935 to replace the Sanitary Board as the town's regulatory body was still not equivalent to a municipal council. G. E. Gent of the Eastern Department at the CO was quite clear that the urban district council was not a 'municipal' authority. This was because it had no powers to collect revenue in its own right. As he observed, 'If it were a strictly Municipal body it would ... have the power to levy rates sufficient for its duties'. ${ }^{21}$ The newly established Urban District Council received its funds as did the old Sanitary Board directly from the Government. Furthermore the electorate for the Urban District council was 'substantially the same as that for its predecessor'. It was still elected by a very limited franchise. ${ }^{22}$ As Norman Miners has claimed, 'this was more a change in nomenclature than in substance'. ${ }^{23}$

This lack of accountability to the indigenous population of Hong Kong is both a cause of and a result of this system, in as much as there were limited official channels through which pressure for

\footnotetext{
${ }^{19}$ Miners, Hong Kong under Imperial Rule, 85. Even in the lower ranks of clerical and technical staff, where most dependencies employed indigenous personnel, Hong Kong employed Europeans. See L. A. Mills, British Rule in Eastern Asia. A Study of Contemporary Government and Economic Development in British Malaya and Hong Kong (London: Oxford University Press, 1942), 418.

${ }^{20}$ G. B. Endacott, A History of Hong Kong (Hong Kong: Oxford University Press, 1973), 199-205.

${ }_{21}$ PRO, GO 1 29/553/10, G. E. Gent, Minute, 23 April 1935.

${ }_{22}$ PRO, CO 129/553/10, Letter from the Colonial Secretary, W. Southorn, 31 July 1935 to the Secretary of State.

${ }^{23}$ Miners, Hong Kong under Imperial Rule, 145.
} 
change could operate. ${ }^{24}$ It meant that any measures of social improvement in the colony were to an extent dependent on Europeans acting in their own self interest or from a sense of paternalism. The problem of disease worked on both these counts. Tuberculosis, in particular, presented an individual threat to the colonizers, given the impossibility, despite a residential apartheid, of complete segregation. It sapped the productivity of workers and thus acted as a brake on economic development. On the other hand, the extent of the disease awakened the humanitarian instincts of colonizers who took their 'civilizing' objectives seriously. This applied particularly to the members of the colonial medical services, who constantly highlighted the appalling living conditions of the Chinese in their annual reports. ${ }^{25}$ This commitment is amply illustrated by the attitude and the work of Percy Selwyn-Clarke, who took over as the colony's medical director in $1938 .{ }^{26}$ It is thus against this political and constitutional background that government attempts to address Hong Kong's poor social conditions have to be considered.

\section{A Health Profile for Hong Kong, 1900-1940}

Table 1 shows population numbers in Hong Kong in the first four decades of the twentieth century. These figures take no account of

\footnotetext{
${ }^{24}$ This 'top down' account of Hong Kong's politics has ignored for reasons of space popular protest which in the interwar period erupted in industrial unrest. See for example, Ming K. Chan, 'Hong Kong in Sino-British Conflict: Mass Mobilization and the Crisis of Legitimacy, 1912-1926', in Ming K. Chan (ed.), Hong Kong between China and Britain (London: M. E. Sharpe, 1994), 27-57.

${ }^{25}$ Of course the colonial medical services have been implicated in the imperial project. There has been an extensive literature on this. See for example the essays in D. Arnold, Imperial Medicine and Indigenous Societies (Manchester: Manchester University Press, 1988); Roy MacLeod and Milton Lewis, Disease, Medicine and Empire. Perspectives on Western Medicine and the Experience of European Expansion (London and New York: Routledge, 1988); B. Andrews and A. Cunningham (eds), Western Medicine as Contested Knowledge (Manchester: Manchester University Press, 1997).

${ }^{26}$ Dr Selwyn-Clarke served in the medical services of the Gold Coast, Malaya and Nigeria before coming to Hong Kong in 1937 where he remained until 1947, surviving internment by the Japanese. He was Governor of the Seychelles from 1947 and then Principal Medical Officer at the Ministry of Health after retirement from 1951-1956. In the 1930s he visited the Soviet Union to 'see the other system at work and what was happening in clinical, preventive and social medicine'. In 1935 he married Hilda Browning who was active in the Labour Movement and acquired the sobriquet of 'Red Hilda' for her activities in Hong Kong. Rhodes House Collection MSS BRIT EMP S470, 'Memoirs of Sir Selwyn Clarke', 74.
} 
TABLE 1

Population Trends for Selected Years

\begin{tabular}{lc}
\hline Year & Hong Kong \\
\hline 1901 & 283,975 \\
1906 & 329,031 \\
1911 & 744,660 \\
1916 & 528,090 \\
1921 & 585,880 \\
1926 & 874,420 \\
1931 & $849,75^{\circ}$ \\
1935 & 988,190 \\
1939 & $1,071,893^{*}$ \\
\hline
\end{tabular}

*This figure does not include an estimated $75^{\circ}$,ooo refugees.

These figures are compiled from the Blue Books PRO CO 133 Hong Kong.

the movements in and out of the colony and are based on the dicennial census held in the colony. The accuracy of the figures cannot be guaranteed but they do show a fluctuating upward trend and indicate the possible extent of the public health problems presented by this increase into a limited urban space.

Table 2 shows the death rates in comparison with the UK. Unlike the steady decline of the UK unsurprisingly Hong Kong's death rates remained at a high level throughout this period with a dramatic

TABLE 2

Crude Death Rates for Hong Kong, for Selected Years with a Comparison with England and Wales

\begin{tabular}{lccc}
\hline & Hong Kong & \multicolumn{2}{c}{ England and Wales } \\
\hline Year & DR & Year & DR \\
1901 & 24.0 & $1901-05$ & 16.0 \\
1906 & 17.1 & $1906-10$ & 14.7 \\
1911 & 21.8 & $1911-15$ & 14.3 \\
1916 & 24.0 & $1916-20$ & 14.4 \\
1921 & 20.2 & $1921-25$ & 12.1 \\
1926 & 15.9 & $1926-30$ & 12.1 \\
1931 & 24.8 & $1931-35$ & 12.0 \\
1935 & 22.9 & $1936-40$ & 12.2 \\
1939 & 56.9 & & \\
\hline
\end{tabular}

These figures are compiled from the Blue Books series above, the Registrar Generals' and Annual Medical Reports PRO CO 131 Hong Kong. Figures for England and Wales come from D. A. Coleman, 'Population', in A. H. Halsey (ed.), British Social Trends Since I9oo: A Guide to the Changing Social Structure of Britain (London: Macmillan, 1988), 36-134, 40. The figures for Hong Kong are at best an approximation. Although this data was collected assiduously in the period, it was not possible to enforce registration procedures effectively, and defining the causes of death was particularly problematic. 
increase at the end of the 1930 . The refugees coming into the colony in flight from the Japanese brought with them smallpox and cholera, and exacerbated the already poor public health record of the colony. ${ }^{27}$

Table 3 shows the principal causes of deaths for Hong Kong for the years 1900-1939. It shows that the epidemic diseases of cholera, plague and smallpox, which had precipitated international efforts to prevent their spread in the nineteenth century, were insignificant as causes of death. Cholera did appear intermittently but never to any great extent except, as already noted, at the end of the 1930 . (There were 363 deaths in 1938 and 626 in 1940.) ${ }^{28}$ To deal with plague quarantine procedures were imposed and were arguably harsh but effective. Hong Kong had suffered an epidemic at the turn of the nineteenth century (1,022 deaths in 1901) but plague ceased to figure as a health problem after 1921. Smallpox cases were low for the period except again at the end of the 1930s when they rose to an alarming 1,833 deaths in 1938. The colonial administration had quarantine procedures and smallpox vaccination programmes to control their incidence within the colony and there were international conventions and organizations in place to prevent their spread by trade and commerce. ${ }^{29}$ These diseases were not a substantial risk for the Hong Kong population in the period. The so-called 'tropical diseases' were also not a significant health risk. Malaria was an important cause of death at the beginning of the century but declined thereafter.

Shula Marks has pointed out in relation to South Africa that the 'great killers were malnutrition and the nutritionally associated infectious diseases, or diseases associated with poverty'. ${ }^{30}$ This can be applied equally to Hong Kong. Beriberi was a disease of malnutrition caused by the consumption of overmilled rice. This did decline in the mid 1930 only to rise again at the end of the decade. However this table strikingly shows that Hong Kong's experience exemplifies the material basis for the health problems of the indigenous populations. Tuberculosis and pneumonia, alongside dysentery and diarrhoea,

${ }^{27}$ See the annual medical reports for 1938-40, PRO, CO, 131/101, CO 131/05.

${ }^{28}$ PRO, CO 131/101, CO 131/105, Annual Medical Reports for Hong Kong, 1938 and 1940 .

${ }^{29}$ See for example N. Goodman, International Health Organisations and Their Work (London: J. \& A. Churchill Ltd, 1952).

${ }^{30}$ S. Marks, 'What is Colonial About Colonial Medicine? And What Happened to Imperialism and Health?', Social History of Medicine 10:2 (1997), 215. 


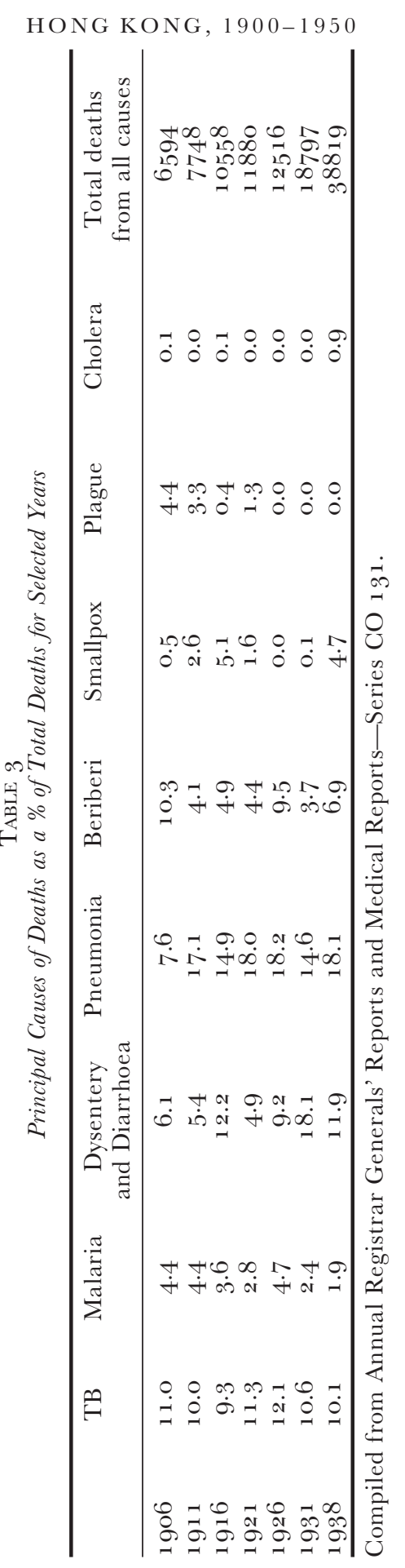


were diseases of overcrowded, insanitary living and working conditions, and they were the biggest killers in Hong Kong throughout the period with no signs of abatement. They were the classic diseases of poverty which could be found in any poor community, whether in temperate or tropical climes. It was the continually high incidence of tuberculosis, in particular, which medical directors highlighted in their annual reports. ${ }^{31}$ Moreover, they constantly drew attention to the link between tuberculosis and the poor living conditions of the Chinese in these reports. Eventually, these officially aired views drew the government into considering the colony's housing problem.

\section{Social Conditions and Tuberculosis}

Tuberculosis was still a leading killer in the UK in 1900, second after heart disease, even though it had been in decline from the 188 os. The cause of that decline has been attributed to rising living standards and/or direct social intervention: sanitary measures reduced the incidence of other epidemic diseases which reduced resistance to tuberculosis. ${ }^{32}$ Koch's discovery of the tuberculosis bacillus in 1882 redefined tuberculosis as an infectious disease, but this did not lead automatically to the adoption of the normal methods of controlling infectious diseases. This would have implied, as Anne Hardy has argued, too great an intrusion into the individual liberties of a considerable section of the community. Instead tuberculosis was projected as a disease of poverty and became the 'social disease' which could be alleviated through improved housing, sanitation and public education. ${ }^{33}$ Mark Harrison and Michael Worboys have argued that tropical medicine experts and the colonial medical services paid little attention to the disease and so it was mainly European-based experts who addressed the problem. This led to a perception of tuberculosis in the colonies also as a 'social disease'. The international epistemic community of tuberculosis experts, whatever the changes in knowledge and whatever part of the world, operated

\footnotetext{
31 As their comments illustrate (see the next section), it may have been the economic costs of tuberculosis with its toll of adults of working age, which led them to concentrate on tuberculosis rather than the biggest killer-pneumonia.

32 See A. Hardy, The Epidemic Streets: Infectious Diseases and the Rise of Preventive Medicine I 856-1900 (Oxford: Clarendon Press, 1993), $211-12$.

${ }^{33}$ Ibid., 255, $263-4$.
} 
within a 'single discourse'. ${ }^{4}$ The way that tuberculosis was approached in Hong Kong supports this contention.

Tuberculosis was not unknown in China and South Asia, but in the rapid urbanization of the late nineteenth century it began to increase in incidence to alarming rates. Deaths from tuberculosis in Hong Kong ran at a very high rate for the whole of the period 19001940 and continued to do so after the Second World War. In 1906 it was estimated that it alone caused nearly $11 \%$ of all deaths amongst the Chinese community. In 1921 it accounted for $15 \%$ of all registered deaths. ${ }^{35}$ In his 1931 report Dr A. R. Wellington openly condemned the situation. Tuberculosis, he pointed out, was a 'chronic and debilitating disease which unfits the individual for the active exercise of his employment months or even years before death'. The mortality figures were therefore an 'incomplete index of the prevalence of the disease' and 'many sufferers returned to their ancestral villages to die'. ${ }^{36}$ Moreover for every death 'there were ten sufferers from it'. When Dr Selwyn-Glarke arrived in the colony in 1937 to take over the medical department the situation was still critical. In his 1938 report he estimated that eight out of ten of all deaths in Hong Kong were due to pulmonary tuberculosis. It was also probable, he claimed, that there were five sufferers from the disease for every death and because of the congestion the 'opportunities for its spread were legion'. ${ }^{37}$ The toll of tuberculosis in this period was by no means a uniquely Hong Kong problem but was general throughout colonial cities of the East. For example, Lenore Manderson has shown how tuberculosis was major cause of morbidity and mortality in the cities of the Malayan peninsula, Singapore especially, before and after $1940{ }^{38}$ In Ceylon tuberculosis and pneumonia follow only malaria, dysentery and diarrhoea as major causes of death between 1900 and $1948 .{ }^{39}$ A Government Commission set up

\footnotetext{
${ }^{34}$ M. Harrison and M. Worboys, 'A Disease of Civilisation, Tuberculosis in Britain, Africa and India, 1900-1939' in L. Marks and M. Worboys (eds), Migrants and Minorities and Health (London: Routledge, 1997), 93, 117.

${ }_{35}$ PRO, CO 131/38, 58, Annual Medical Reports, Hong Kong, I906, I92I.

${ }^{36}$ PRO, CO 131/85, Annual Medical Report, Hong Kong, I93 I. Dr A. R. Wellington was Director of Hong Kong's medical services, 1929-1937.

${ }^{37}$ PRO, CO 131/101, Annual Medical Report, $193^{8 .}$

${ }^{38}$ L. Manderson, Sickness and the State: Health and Illness in Colonial Malaya, I87oI940 (Cambridge: Cambridge University Press, 1996), $120-2$.

${ }^{39}$ See M. Jones, Health Policy in Britain's Model Colony: Ceylon, I90o-1948 (forthcoming).
} 
in 1910 to look into the problem of tuberculosis in this colony found that its incidence in Colombo alone had increased from 25 per thousand in 1899 to 44 in $1910 .{ }^{40}$ Indeed, the rapid urbanization of colonial communities replicated the living conditions and health problems of British cities in the nineteenth century.

In 1949 the Hong Kong Government commissioned a report on the disease from Dr A. S. Meade who was on the panel of tuberculosis specialists attached to the World Health Organisation. His findings supported the pre-war estimates and showed that the situation was unchanged by the late 1940 . Table 4 , taken from this report, shows the incidence of the disease in the colony before it became a notifiable disease. These figures, as Dr Meade acknowledged were an approximation only. The slight decline in the 1930 s shown in this table and in Table 3 was not sustained. Dr Meade estimated that in 1949 tuberculosis accounted for $16 \%$ of all deaths recorded, which was an increase on the $14.6 \%$ of the previous year. ${ }^{41}$

The medical authorities of Hong Kong attributed this high incidence of the disease both to personal and cultural habits, and to the socio-economic conditions of the colony, as did the medical officers in other colonies. ${ }^{42}$ In 1911 , for example, Dr J. M. Atkinson (medical director, 1900-1912) argued in his annual report that the high

TABLE 4

Deaths from Tuberculosis for Selected Years

\begin{tabular}{lc}
\hline Year & Rates Per Hundred Thousand \\
\hline 1920 & 321.2 \\
1922 & 328.3 \\
1924 & 339.0 \\
1926 & 269.2 \\
1928 & 330.9 \\
1930 & 237.7 \\
1932 & 226.6 \\
1934 & 230.7 \\
1936 & 244.5 \\
\hline
\end{tabular}

Compiled from PRO, CO 1 29/629/10, Dr A. S. Meade, Report on Tuberculosis in Hong Kong I949, Annexure G, 23.

${ }^{40}$ PRO, CO 57/177, Sessional Papers, I9o9-1910, Ceylon, Report of the Tuberculosis Commission.

${ }^{41}$ PRO, CO 1 29/629/10, Dr A. S. Meade, Report on Tuberculosis in Hong Kong I949, Annexure $G, 23$.

${ }^{42}$ See for example, Manderson, Sickness and the State, 120-2; M. Jones, Health Policy in Britain's Model Colony: Ceylon, I90o-1948 (forthcoming). 
death rates from tuberculosis in Hong Kong were caused in part by the 'inveterate habit of lower class Chinese of spitting in public buildings, offices, staircases, footpaths and wharves'. ${ }^{43}$ Twenty years later in 1931, Dr A. R. Wellington pointed out that for every death in the colony because of the habit of spitting there were '20,000 living incubators of the disease each adding his daily quota of microbes to the stock already existing'. ${ }^{44}$ Dr Selwyn-Clarke also claimed in 1938 that the population was 'exposed daily to mass infection' because of the 'universal and disagreeable habit of spitting; they are ignorant of the ways in which the disease is spread'. ${ }^{45}$

However, at the same time that these men castigated individuals for their part in spreading disease, the main emphasis in their annual medical reports was on the socio-economic causes of the disease. For example, the director of Hong Kong's medical services, Dr J. T. C. Johnson (medical director, 1913-1923) included a section on housing and disease in his 1921 report. He pointed out that since the beginning of the century 'it had become more and more difficult to find room for the ever increasing Chinese population'. Old houses formerly occupied by Europeans and standing in their own grounds and old small Chinese houses have been demolished and replaced by many-storeyed Chinese tenement dwellings'. He estimated that in health districts 4 to 8 which formed the central Chinese part of Victoria, the average number of persons per floor had increased from $7.6 \%$ persons in 1911 to 10.17 in 1921 a rise of $33 \%$ or more. But given that shops and stores on the ground-floor levels were not occupied, the real figures for the upper floors were higher than that. This overcrowding had 'naturally an effect on the spread of infectious diseases'. ${ }^{46}$

In 1918 the government sanctioned an investigation into an epidemic of meningitis by Peter K. Olitsky of the Royal Institute for Medical Research. One of the major causes he cited for the outbreak was the overcrowding in the colony. 'The area ways and the streets and lanes are so narrow and the houses so high ... that not only ventilation and light becomes deficient but the air is always damp'. His description of one house he visited is worth repeating in full. On June 7 th 1918 he made an inspection of no. ${ }_{15}$ Chinese Street at $11 \mathrm{pm}$. The house had three storeys, its cubic footage was nearly

\footnotetext{
43 PRO, CO 131/46, Annual Medical Report, Hong Kong, I9I I.

44 PRO, CO 131/85, Annual Medical Report, Hong Kong, I93I.

45 PRO, CO, 131/101, Annual Medical Report, Hong Kong, I938.

46 PRO, CO 131/58, Annual Medical Report, Hong Kong, I92 I.
} 
6 ,ooo feet with a total window area of $5^{1}$ square feet. One of the windows opened onto a narrow street and the other into a chimney like area way. The window and the door were both bolted which was the usual practice apparently to prevent burglary and 'the air was quite foul'. The first floor was divided into four cubicles, measuring seven feet wide, eight feet long and six feet high; these housed between them 13 people and in a narrow hallway there were boards and trestles which a further seven people occupied. The second floor housed 17 people. The legal restriction for a house of this size, he pointed out, was seven to nine people a floor. His suggestions for the government were that they reclaim land, colonize the New Territories and in recognition that the overcrowding was partly because people needed to live where the work was, at the same time improve the transit facilities. ${ }^{47}$

Dr Wellington included a graphic description of housing in Hong Kong in his 1931 report and linked the 'overcrowded and insanitary' buildings to disease. In some houses, he pointed out, 'tiers of bunks were placed against walls'. In others, 'rooms were divided into cubicles or cabins of 8 feet by 8 feet and partitions of 6 feet'. There was little or no room for kitchens and 'latrines often limited to a pail on the roof'. 'Year by year' he said, 'the Sanitary Department and the building authority have made efforts to improve the situation' but the 'task almost sisyphean in itself ... is rendered more difficult by the paucity of water and by the opposition put forward by property owners and occupiers'. ${ }^{48}$ In 1934 he estimated that the population density in the town fronting Victoria harbour was 1 , ooo per acre. ${ }^{49}$ He was still stressing this in 1936 . He noted the 'quickening social consciousness' amongst the 'artizan class' and 'the resultant desire to avail themselves of improved housing accommodation wherever such is made available', but also that the 'unskilled labouring classes ... are still found densely packed in tenement houses deficient in light and air'. ${ }^{50}$

In his first report as medical director in 1938, Dr Selwyn-Clarke argued quite categorically for the link between tuberculosis in the colony and the overcrowding, which had worsened as a result of the Japanese invasion of China. The 'average poorer class Chinese tene-

${ }^{47}$ PRO, CO 131/68, P. K. Olitsky, Sessional Papers, Hong Kong, Report on Investigations of the Outbreak of Epidemic Meningitis in Hong Kong, I9I8.

${ }^{48}$ PRO, CO 131/85, Annual Medical Report, Hong Kong, I93I.

${ }^{49}$ PRO, CO 131/92, Annual Medical Report, Hong Kong, I934.

${ }^{50} \mathrm{PRO}, \mathrm{CO}$ 131/95, Annual Medical Report, Hong Kong, 1936. 
ment today houses from $30-60$ per floor as compared to $15^{-1} 7^{\prime}$ before the invasion. ${ }^{51}$ According to Dr Meade the situation in the later 1940 os had if anything deteriorated with the further refugee influx from China. Furthermore this overcrowding had been exacerbated by the action of the authorities. 'The Urban Council have been conducting an active campaign against squatters ... who have been obliged to leave their illegal huts and seek accommodation elsewhere, some to erect huts in less accessible sites, others to crowd into the already overcrowded tenements'. This led, he said, to an 'unimaginable' degree of overcrowding and 'it was not surprising' that there had been an increase in the numbers suffering from tuberculosis. 'One case of pulmonary tuberculosis was recently to be found to be living on a floor legally capable of housing 10-12 persons, but occupied by 23 families'. This kind of situation was replicated throughout the colony. There would be little hope of improvement, he argued, until the density of the population was reduced. ${ }^{52}$

The problem of tuberculosis and its link with the living conditions of the Chinese population of the colony was thus well documented in these official reports. The question is to what extent did the government act upon this information?

\section{Responses Targeted at the Individual}

Public health strategies take three main forms. The first obvious response is the treatment of the sufferer of the disease by the establishment of curative facilities. Secondly, to prevent disease individuals can be targeted and induced to take responsibility for their own health by changes in behaviour. In addition, societies can adopt collective preventive measures such as vaccinations, isolation of sufferers, and notification of diseases. These can be compulsory or voluntary. Thirdly, the health of societies can be improved through tackling the underlying socio-economic causes of disease. There is evidence that the government adopted all these strategies, albeit rather belatedly and patchily, in Hong Kong in this period. In the case of tuberculosis this meant preventing transmission of the disease through exhortations to change individual behaviour; the treat-

${ }^{51} \mathrm{PRO}, \mathrm{CO}$ 131/101, Annual Medical Report, Hong Kong, 1938.

52 PRO, CO 1 29/629/10, Dr A. S. Meade, Report on Tuberculosis in Hong Kong I949, 23 
ment of the sufferer and if possible isolation to limit the number of contacts. (As already noted the extent of tuberculosis in populations made it inexpedient to make this compulsory.) An adjunct of these policies was to make the disease notifiable (this was not done in the UK until 1912). The definition of tuberculosis as a 'social disease'a disease of poverty-also meant that authorities recognized and acted upon the contributory social conditions.

The government and medical authorities of Hong Kong were quick to address the cause as a behavioural problem. Injunctions to the Chinese to refrain from spitting, for example, in order to halt the spread of disease were a constant theme throughout the whole period. As the 1911 medical report noted, for example, notices pointing out the health hazards of this habit had been posted in public buildings, tramcars and ferry boats; lectures were given and leaflets distributed in the hope of correcting the behaviour. ${ }^{53}$ These were minimal policies and entailed little effort or more importantly expense for the government. At the end of the period, Dr Meade noted the attempts to limit the spread of disease by similar methods: 'by loud speaker vans, by public notices, by pamphlets, by cinemas and by instruction of the patient in the clinic, in hospital and in his own home'. All this was to little avail given the extent of overcrowding. ${ }^{54}$

Treating the sufferer was more costly and the record of the Hong Kong government on this is not a good one. Despite the extent of tuberculosis, as late as 1936 Dr Wellington complained that there were 'no sanatoria and no infirmaries other than the Chinese hospital where poor tuberculosis patients could find shelter and treatment'. Even this help was minuscule, given the scale of the problem. The Tung Wah Hospital, situated in the most congested part of Victoria had only 36 beds for tuberculosis patients. Prevention relied on the inadequate application of building regulations to prevent overcrowding, such as the erection of unauthorized buildings and

53 PRO, CO 131/46, Annual Medical Report, Hong Kong, I9I I. Similar injunctions to prevent the spread of tuberculosis appeared in handbills in the UK at the end of the nineteenth century. For example in Oldham the handbill forbad spitting in public rooms, railway carriages and other public places. A. S. Wohl, Endangered Lives: Public Health in Victorian Britain (London: Methuen, 1984), 131. There was a similar government anti-spitting campaign in Singapore, Manderson, Sickness and the State, 122.

${ }^{54}$ PRO, CO 1 29/629/10, Dr A. S. Meade, Report on Tuberculosis in Hong Kong I949, 23. 
cubicles. To Dr Wellington the wonder was 'not that so many people contract tuberculosis but that so many escape'. ${ }^{55}$ The need for hospital or infirmary accommodation for patients was pointed out constantly in subsequent reports in the 1930s. This was in marked contrast to Ceylon, for example, where an Anti-Tuberculosis Fund, set up in 1910 with a combination of government funding and public donation, had established an Institute, dispensary and sanatorium for the treatment and care of sufferers of the disease by $1919 .{ }^{56}$

Dr Selwyn-Clarke spurred on by what he perceived to be a crisis situation by the late 193 os launched an active campaign against the disease, which encompassed all strategies which could be undertaken by individuals at all levels of society. ${ }^{57}$ Tuberculosis was made a notifiable disease in 1939. He set up an Anti-Tuberculosis Association chaired by a M. K. Lo, with an annual membership fee of $\$ 5$. The objects of the association were to accept donations and invest the money in order to provide the funds to study the incidence, prevention and cure of the disease, and to educate the public in its cause and prevention. ${ }^{58}$ Dr Selwyn-Clarke also embarked on his own propaganda campaign against the disease in 1939-1940 through a series of radio broadcasts, in conjunction with Mr Ho Kam-tong, and public lectures. ${ }^{59}$ In these lectures and broadcasts he appealed both to the humanitarian instincts and the self-interest of his Chinese and European listeners, and he ran through the whole gamut of factors which contributed to tuberculosis, in which the social, environmental and economic were given prominence. The major problem, he argued, was that the majority of the population of Hong Kong lived on earnings which were 'barely sufficient to make it possible to obtain enough food of the proper quality, reasonable shelter and satisfactory clothing of the body'. The result was that they succumbed to the disease and then became either incapable of a full day's work or any

55 PRO, CO 131/85, Annual Medical Report, Hong Kong, I93I.

6 SLNA PF 2436B, Colombo, Ceylon, 'The Need of Special Measures for Dealing with Tuberculosis, 1909-1913'; C. G. Uragoda, A History of Medicine in Sri LankaFrom the Earliest Times to 1948 (Colombo: Sri Lanka Medical Association, 1987), $24 \mathrm{O}-1$.

57 PRO, CO 131/101, Annual Medical Report, Hong Kong, I938.

${ }^{58}$ Rhodes House Collection MSS BRIT S470, 'Constitution of the Hong Kong Anti-Tuberculosis Association'.

${ }_{59}$ M. K. Lo and Ho Kam-tong were members of the Chinese elite but it is difficult to find firm information about them. Ho Kam-tong was the holder of an OBE and possibly the brother of Sir Robert Ho Tung. 
work at all. In this state the worker and his family, with no system of insurance or relief, could not buy food or pay the rent and ended up on the pavement. ${ }^{60}$

There were no quick fixes for the economic problems and the overcrowding but there were things which individuals could do. $\mathrm{He}$ appealed to employers of any labour, from 'a houseboy and amah to clerks, factory workers and coolies' to pay sufficient wages and pay attention to their workers' nutrition. In the absence of state help he advocated a kind of occupational welfare of the kind that some Chinese employers in the colony offered. 'It is one of the bright spots of this city of ours that quite a number of Chinese employers see that their workers have at least one good meal a day' and provide their workmen with 'healthy living and sleeping quarters' ${ }^{61}$

People could help themselves in their everyday lives. They could ventilate their houses, avoid physical contact with infected persons, in particular not let infected persons kiss babies, not share dishes, basins, spoons etc., encourage early detection, isolation and treatment of the disease and, of course, not spit. ${ }^{62} \mathrm{He}$ was careful to cite Chinese sources in support of this last injunction. Both Dr Sun Yatsen and Madame Chiang Kai-shek had said it was 'the duty of the good Chinese to refrain from spitting'. ${ }^{63}$ Self-interest was not neglected in these pleas. 'From the purely selfish standpoint it is a very short-sighted policy to allow a servant to live in a crowded cubicle or in a dark ill-ventilated hole under the stairs and so run the risk of infection. Tuberculosis is no respecter of persons and can attack the rich too'. ${ }^{64}$

${ }^{60}$ MSS BRIT S470, 'Address delivered on Tuberculosis at the Chinese Methodist Church Wanchai, Hong Kong, 28 January 1940'.

${ }^{61}$ Ibid. Action like this which could also include housing for employees was influenced by traditional Chinese protective structures. See Hong Zhou, 'The Origins of Government Social Protection Policy in Hong Kong, 1842-1941' (Unpublished Ph.D. Dissertation, University of Brandeis, 1991).

${ }^{62}$ MSS BRIT EMP S470, 'Three Radio Broadcasts about Tuberculosis 29 December 1939, 6 January 1940, 13 January 1940. Part 1'; 'Address Delivered on Tuberculosis at the Chinese Methodist Church'.

${ }^{63}$ Injunctions against spitting were one of the moral prescriptions of the New Life Movement founded in 1934 by Chiang Kai-shek. Its rules for behaviour included injunctions about personal hygiene, moral character and social duties. In this case it appears that Selwyn-Clarke has co-opted these ideas for his lectures and broadcasts. See 'Rules for Behaviour. New Life Promotion Society of Nanchang' (Nanchang, 1935), 216-20, reprinted in Pei-kai Cheng and M. Lestz, with J. Spence, The Search for Modern China: A Documentary Collection (New York: W. W. Norton, 1999), 300.

${ }^{64}$ MSS BRIT EMP S470, 'Three Radio Broadcasts'. 
The colonial government's role in the fight against the disease was not totally ignored in this campaign. Dr Selwyn-Clarke acknowledged that not enough had been done. The isolation of infected persons was practically impossible, given the housing conditions in the colony, and so hospital accommodation was a vital necessity, but apart from a few wards in general hospitals there were no specialist hospitals or sanatoria. ${ }^{65}$ The government, he claimed, was planning to remedy this neglect by setting up health centres for maternal and child welfare which would have attached to them also specially trained tuberculosis doctors; $\$ 100$,ooo had been earmarked in the 1940-41 estimates for this purpose. A Nutrition Research Committee had been established, a Town Planning Board (see below) was to devise schemes for zoning, town planning and slum clearance and a committee was set up to reorganize the hospitals. This was a belated and doomed attempt, given the international situation, to rectify decades of neglect. His campaign thus had the support of the government which had come to recognize its part in the prevention of tuberculosis.

\section{Housing Policies}

However, the principal problem as Dr Selwyn-Clarke and his predecessors constantly emphasized was the inadequate and overcrowded housing. Housing in the colony was regulated by a series of ordinances based on similar public health legislation in the UK. The 1903 Public Health and Buildings Ordinance was the basis for regulating building in the colony until the reforms of 1935 which restated and updated these regulations. ${ }^{66}$ This legislation was concerned with such matters as the standard of building with regard to occupancy density, latrine accommodation, kitchen facilities, access to light and air, plus drainage, the control of nuisances, cleansing, rubbish disposal and so on. The first town planning ordinance was not passed

\footnotetext{
65 The isolation of infected people from the community has been cited as one reason for the decline in tuberculosis in Britain. See D. Porter, Health, Civilisation and the State: A History of Public Health from Ancient to Modern Times (London: Routledge, 1999), 284.

${ }_{66}$ PRO, CO 130/7, Public Health and Buildings Ordinance, 1903, CO 130/12 Urban Council Ordinance, 1935, Public Health (Sanitation) Ordinance, 1935. See also E. G. Pryor, Housing in Hong Kong (Hong Kong: Oxford University Press, 1983), $15^{-19}$.
} 
until 1939; this was intended to 'make provision for the systematic preparation and approval of plans for the future layout of existing and potential urban areas as well as for types of building suitable for erection therein'. ${ }^{67}$

The public health ordinances laid down minimum standards but even these as the previous discussion has shown could not be enforced effectively. The housing needs of the population overwhelmed these regulations and there was also resistance from the property owners as there had been in the UK to adhere to them. A trawl through the surviving records of the Sanitary Board, for example, is a testament to these attempts to circumvent even these basic regulations ${ }^{68}$ However, regulations of this sort did not address the real problem. As Dr Selwyn-Clarke pointed out in his tuberculosis talks the main factor was that the general population were too poor to pay an economic rent for decent accommodation.

The government did show some awareness of the roots of the problem; it was not a story of complete neglect. In 1923 it set up a first housing commission under the chairmanship of H. E. Pollock. Their recommendations echoed some of those of Olitsky's 1918 report, and like most other recommendations on the subject supported education of the Chinese to induce them to modify their habits. They agreed that the government should open up land on the Kowloon Peninsula and improve transport from there to Victoria where the work was located. In conjunction with this a reduction in ferry fares should be arranged.

However, they went further than Olitsky in suggesting government subsidies not only for transport but also for housing itself. They suggested several policies to make the building of houses a more attractive proposition. First, the government should grant cheap land to people on condition that they built a tenement within six months. It should allow workmen to live on the ground floors of houses whilst they erected the upper floors. It should sell land cheaply to employers to build houses for their workers. Lastly, the government itself should build and rent out houses for building labourers. ${ }^{69}$ No action was taken on these recommendations.

\footnotetext{
${ }^{67}$ PRO, CO 130/13, Town Planning Ordinance, 1939; Pryor, Housing in Hong Kong, 22.

${ }_{68}$ PRO, Hong Kong, HKRS 205, 58, Sanitary Board Papers.

${ }^{69}$ PRO, CO 131/68, H. E. Pollock, R. H. Kotewall and W. S. Bailey, Sessional Papers, Hong Kong, Report of Housing Commission, 1923; Pryor, Housing in Hong Kong, 19-21.
} 
As well as inertia and a laissez-faire philosophy of government it is worth noting at this point that there was a third factor which inhibited any government action of this kind, and that was finance. Colonies were expected to be entirely self-financing. The Hong Kong government had limited reserves to draw upon. Having no natural resources which could be taxed and needing its status as a free port, it relied heavily on property taxes for income. The possibility of income tax was raised in 1916 but dropped and not considered again until 1938. ${ }^{70}$ The Imperial Government facilitated loans at cheap rates of interest but these were usually only allowed for capital projects such as waterworks and definitely not for the maintenance of social services. Help from the imperial government for welfare initiatives did not become possible until the passing of the Colonial Development and Welfare Acts of 1940 and $1945 .^{71}$ Hence any government action which required expenditure was subject to enormous resistance, not just from the propertied who benefited most from the slum conditions of the colony but also from a colonial secretariat imbued with 'Gladstonian' economics. Such financial constraints applied to all crown colonies. The colonies of the Malayan peninsula and Ceylon for example were no more successful in tackling the environment of their cities or improving the housing of their poorer inhabitants. $^{72}$

The problem remained a festering, but also as we have seen, an officially acknowledged one, for another 12 years before it was addressed again, and this time it was clearly the extent of tuberculosis which was the precipitating factor. A second housing commission was established in 1935 'to enquire into the housing difficulties in Victoria and Kowloon with special reference to overcrowding and its effect on tuberculosis'. In a personal letter to Sir John Maffey (Permanent Under-Secretary of State at the Colonial Office), Sir William Peel then Governor explained that he had set up the commission especially in relation to tuberculosis 'which is a dreadful scourge here' presenting a serious problem which 'must be tackled'. ${ }^{73}$

${ }^{70}$ Miners, Hong Kong under Imperial Rule, 113.

${ }^{71}$ See PRO, CO 54/720 for a discussion at the Colonial Office for how the loans system should operate, and D. J. Morgan, The Origins of British Aid Policy: The Official History of Colonial Development I924-45. Volume I (London: Macmillan, 1980).

72 See Manderson, Sickness and the State, 1 22-4; M. Jones, 'British Colonial Health Policy 1900-1940: Ceylon and the Asian Colonies' (Unpublished Ph.D. Dissertation, University of Bristol, 2000), $130-59$.

${ }^{73}$ PRO, CO $129 / 553 / 4$, Letter from Sir William Peel to J. Maffey, 18 January 1935 . 
The commission was composed of N. L. Smith, the Secretary for Chinese Affairs, R. M. Henderson, Director of Public Works, W. E. L. Shenton, an unofficial member of the Legislative Council, W. J. Carne, Head of the Sanitary Department, Dr G. W. Pope a medical officer of health, two architects, G. G. Wood and W. H. Owen, who was in the public works department. This commission also included two Chinese, R. H. Kotewall, who was an unofficial member of both the Executive and Legislative Councils and Dr Li Shu-fan, who was an unofficial member of the Sanitary Board and Chair of the Board of Directors of the Yeung Wo private hospital. ${ }^{74}$

The Commission did not report until 1938, citing as excuses for its dilatory response the international situation and the need to gather information from elsewhere. The authors of the report did not feel it necessary to make the link between overcrowding and tuberculosis as they argued that it was obvious. 'Hong Kong is a powerful magnet; the struggle for existence is severe ... it is only too common to find three men doing the work of one and sharing the pay', plus everyone in work usually had a number of relatives to support. The overcrowding thus arose from the poverty which made rents unaffordable. The solution in the colony was to provide more and better housing, decentralize the population and reduce building density. However, the report categorically stated, the provision of adequate housing for the poorer classes could 'not be left to private enterprise unassisted. If the housing is to be acceptable the rent ... will be uneconomic for the poor'. Therefore, the authors argued 'social services need to be provided . . . as in Europe.' If working class housing was built and slum clearance undertaken then financial provision would have to be made firstly, for new housing for those who could afford a small economic rent. Secondly, for new housing for those who can only be housed at a loss, and thirdly for compensation for slum clearance. Housing should therefore be subsidized and the funds raised through loans, a special tax or an issue of housing shares. ${ }^{75}$

However, the authors of the main report rejected W. H. Owen's appendix which argued for even greater subsidy, on the grounds that his proposals were too 'controversial' and 'impractical', although they served to 'illustrate the conclusions in the report'. Furthermore, they

\footnotetext{
${ }^{74}$ PRO, CO 1 29/553/4, Letter from W. Southorn, Colonial Secretary to Secretary of State, 27 May 1935 .

${ }^{75}$ PRO, CO 131/106, Sessional Papers, Report of the Housing Commission 1935; Pryor, Housing in Hong Kong, 21-3.
} 
argued, his plans for living accommodation which included a shower which doubled as a latrine, also exemplified the difficulties in applying to Hong Kong 'methods adopted elsewhere', given that the standards of housing as proposed by Owen were 'below those acceptable in many European countries' ${ }^{76}$

Nevertheless, the Commission had clearly done their homework with regard to the solutions found elsewhere, in particular the UK. In a letter to the Secretary of State in May 1935 at the beginning of the commission's sittings, W. Southorn, the Colonial Secretary, had asked the Colonial Office to send 'any publications in connection with slum clearance and the housing of the working classes which would be based on English experience'. It is recorded that copies of UK housing legislation and circulars were sent to the Governor in August of that year. ${ }^{77}$ Dr Wellington, himself, while on leave in Britain, consulted the housing experts on the London County Council and the Ministry of Health, and visited two council estates in London-the Grosvenor Estate of Westminster Borough Council and the China Walk Estate of the London County Council. ${ }^{78}$ Clearly the interest was in implementing a policy transfer and initiating public housing, as far as was possible, at least in the same direction as in the UK.

Unfortunately, whilst the political will may have been there the question of financing such a measure raised considerable difficulties. The correspondence between the Colonial Office and the Governor, Sir Geoffry Northcote, on housing initiatives in the year following the report centred on this question of finance. There were several schemes being considered in 1939. One of the basic difficulties, Sir Geoffry pointed out, was the shortage of suitable building land in the central area. This could be dealt with by reclamation on Hong Kong island and Kowloon, the encouragement of suburban development for the better off, using some of the land now used by the military in the centre of Victoria, and getting rid of inessential activities there. The proposed Town Planning Committee would consider all these schemes but the question was how 'to finance whatever schemes were adopted'. A 'fund of considerable size' would be needed, he argued, to meet the initial expense. He felt a case could

${ }^{76}$ PRO, CO 131/106, Sessional Papers, Report of the Housing Commission 1935, 4 and Appendix II.

7 PRO, CO 1 29/553/4, Letter from W. Southorn, Colonial Secretary to Secretary of State, 27 May 1935; Letter from the Ministry of Health, 9 August 1935.

${ }^{78}$ PRO, CO 1 29/553/4, Letter from Dr Wellington, 29 July 1936. 
be made for raising a loan but 'it might be that some worthwhile schemes' might not be 'self-supporting', as would be required for a loan (see above). By worthwhile he made plain he meant 'worthwhile from a social point of view'. Therefore, the colony was justified in raising the money partly from income and possibly partly from the existing surplus from the Exchange Fund, which at the present time had assets which exceeded its liabilities. There was a surplus to play with of $£_{25}$ o, 000 which should be used for 'some major purpose of long-term benefit to the community at large'. Sir Geoffry proposed then that an initial sum of $\mathrm{HK}_{5}$ million be transferred from the Exchange Fund to a new 'Improvement Fund' which in addition should receive annually half the net addition to the surplus of the Exchange Fund. The Improvement Fund would be available for 'substantial schemes of re-planning and reclamation and even re-housing schemes but not for ordinary government construction schemes like hospitals for example. ${ }^{79}$

The plan met with a sympathetic response at the Colonial Office but as Gerard Clauson pointed out, it had been thought up by one of their number, Sydney Caine. Clauson thought the plan was 'ingenious and sound' but whilst he agreed in principle he thought that the Exchange Fund was not as good as it was owing to the international situation and that the plan could 'not be actuated in the present insecure position'. ${ }^{80}$ A. N. Galsworthy also accepted its necessity. It was clear, he said, that 'any comprehensive housing scheme would need large funding', a loan was no good because it would only be able to finance 'self-remunerative schemes' but not necessarily those good from a 'social point of view'. Therefore a large fund raised by other means was 'desirable'. ${ }^{81}$ Sir John Campbell, the Colonial Office financial adviser, also raised no objection but commented ominously that the 'Treasury would need to see it and they won't like it'. ${ }^{82}$ As it turned out of course the battle with the Treasury was never to be, as a much harder struggle ensued.

This Government initiative was overtaken completely by the Japanese occupation of the island from December 1941, but it

${ }^{79}$ PRO, CO 129/576/1, Letter from Sir Geoffry Northcote to the Secretary of State, 2 February 1939.

${ }^{80}$ PRO, CO 1 29/576/1, G. Clauson, Minute, 25 March 1939.

${ }^{81}$ PRO, CO 129/576/1, A. N. Galsworthy, Minute, 17 March 1939. Clauson, Caine and Galsworthy, were attached to the Social Services Department set up at the Colonial Office in 1938.

${ }^{82}$ PRO, CO 1 29/576/1, Sir John Campbell, 21 March 1939. 
does provide evidence that the problem of the housing conditions of the Chinese population had entered the agenda of the pre-war colonial government and that it was on the point of implementing policy to deal with it, even to the extent of subsidizing housing out of government income. The motive for this was the extent of tuberculosis in the colony but rather than just tackling this from a curative or individual preventive viewpoint, the government was prepared to tackle the much wider cause-the socio-economic conditions.

There is a further post-script to this account. The post-war government took up the cudgels of housing where its predecessor had left off. In this case the pressing need was the numbers of refugees coming into the colony from mainland China. The genesis of the post-war scheme developed from a voluntary initiative. In 1947 the Lord Mayor of London's Air Raid Distress Fund made a donation of $£ 14$, ooo to the Hong Kong Social Welfare Council. According to Robin Hutcheon, a prominent member of this council was the Right Reverend R. O. Hall, the Anglican Bishop of Hong Kong, who wanted to launch a society to build houses for workers to be run on humanitarian principles on the lines of the Octavia Hill housing managers. The Hong Kong Housing Society was established in April 1948 'to provide, found, secure, promote, encourage and operate housing and its associated amenities on such an economic basis as is suitable for persons of small income'. ${ }^{83}$ This could be cited as an example of the government standing back and presuming that self-help would solve the problem, in line with the accepted view of such social welfare initiatives in Hong Kong before $1953 .{ }^{84}$ However, it also follows a pattern of mixed voluntary/state activity in social policy both at the imperial centre, certainly before 1945 , and in other British colonies in as much as the government soon stepped in and provided funding to enable the Society to expand its activities. ${ }^{85}$

In the words of one Colonial Office official, A. J. Fairclough, in $195^{\circ}$ the government of Hong Kong had " "turned up trumps" on

R. Hutcheon, The First Fifty Years of the Hong Kong Housing Society (Hong Kong: Chinese University Press, 1998), 4-5.

${ }^{84}$ See, for example, Jones, Promoting Prosperity, 181.

${ }^{85} \mathrm{See}$, for example, D. Fraser, The Evolution of the British Welfare State (Macmillan, 1984) and M. Jones, 'Infant and Maternal Health Services in Ceylon, 19oo-1948: Imperialism or Welfare', Social History of Medicine, 15:2 (2002), 263-89 for an example of how this worked for infant and maternal welfare services in Ceylon. 
this question of housing' in devising a scheme which funnelled money from the Colonial Development and Welfare Fund to the Hong Kong Housing Association to set up a pilot scheme which would provide subsidized housing for the 'lower paid strata of Hong Kong's population'. ${ }^{86}$ The Governor, Sir Alexander Grantham, had made clear in discussions with the Secretary of State in the summer of $195^{\circ}$ that he 'considered the provision of adequate housing, particularly for the lower paid sections of the community, one of the most important development needs of the Colony' and that 'he intended to devote a large part of Hong Kong's Colonial and Development allocation of $£ 1$, OOO,OOO to this aspect of development work' ${ }^{87}$ However, it was considered expedient in the first instance to start a small-scale scheme to see how it worked. It was proposed to build ' 370 small flats in eight blocks on two sites.... These flats which will be built for the lower-income groups, will not only provide improved living conditions for the actual tenants, but will indirectly benefit others by relieving congestion elsewhere and may be expected to encourage employers to embark on similar schemes for their employees'. To ensure that rents could be kept low a grant from the CDW fund of $£_{13}, 5$ oo would pay for 'site formation, construction of access roads, and installation of water and drainage'. These things would then not be a charge on the actual flats. Once this was done, the houses could be constructed by the Housing Society. The Society would be used to organize the pilot scheme, with the provision that at some time in the future it would be reconstituted as an Improvement Trust. This trust, which would have 'considerable unofficial representation', would be responsible for housing projects in the colony, under government financial supervision. ${ }^{88}$

This was indeed a small inroad into the housing problem of the

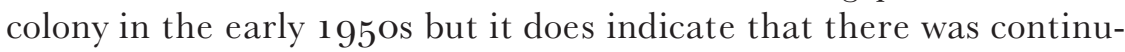
ity in housing policy from the 1930 os to the 195 os which survived the hiatus of the Japanese occupation. Both before and after the war the government recognized that the fundamental problem was the poverty of the population and their inability to pay an economic rent for accommodation. Furthermore, there was a willingness to acknowledge that the only solution to this was for the government to subsidize housing for the working classes.

\footnotetext{
${ }^{86}$ PRO, CO 129/627/3, A. J. Fairclough, Minute, 17 April $195^{1 .}$

${ }^{87}$ PRO, CO 1 29/627/3, Colonial Office Memorandum, 5 May $195^{1 .}$

${ }^{88}$ Ibid.
} 


\section{Conclusion}

There is no doubt that the Shek Kip Mei fire was a trigger to encourage the colonial government to act quickly and effectively to solve the housing crisis. There is no doubt also that the colonial government of Hong Kong was reluctant to intervene and take responsibility for the well-being of the indigenous population before this time. In mitigation of the colonial government's inactivity, it should be noted that even the British Government did not really address the fundamental problem of poverty and housing until the 1919 Housing Act which provided for central government subsidy of housing for the working classes. However, what this detailed analysis of government initiatives in housing shows is that there was an evolutionary process afoot. The impetus for government intervention in the interwar period stemmed from the health problems of the colony and in particular the appallingly high incidence of that classic disease of povertytuberculosis. It was tuberculosis which prompted the response that housing for the working class should be subsidized by the government. This lends support to Peter Baldwin's questioning, in his study of European states and public health, of the thesis that government initiatives in public health were determined by the nature of the state. He suggests rather that it could be the other way round and that instead 'prophylactic imperative' could mould the 'political regime and shape ideological traditions'. ${ }^{89}$ These tentative moves towards state intervention in Hong Kong were overwhelmed by events. However, although the emphasis shifted after the war from public health to the broader problem of the 'appalling overcrowding and squalor' caused by the dearth of adequate housing, and the economic costs of having squatters in low density housing on valuable land, the issue of subsidized housing was once more taken up. ${ }^{90}$

Are there broader lessons to be learnt from this about the nature of Hong Kong's colonial state? Firstly, it reveals that there was a process of policy transfer from the UK to the colony, and that social policy did develop on a similar trajectory as in the metropolitan centre. This was of course a much slower and patchier development in comparison with the UK, and even with other British colonies but policy learning did take place. Secondly, this is not an attempt to

${ }^{89}$ P. Baldwin, Contagion and the State (Cambridge: Cambridge University Press, 1999), 38 .

90 PRO, CO 129/627/3, Colonial Office Memorandum, 5 May 1951. Castells, Goh and Kwok, The ShekKipMei Syndrome, 18, 41 . 
excuse the decades of neglect of the Chinese population by the colonial government, but to argue that social policy began in 1953 with the public housing projects would be to ignore the discussions and initiatives (some albeit aborted) which had preceded this policy. The colonial state of Hong Kong was on a gradual learning curve and was not so obviously subject to radical shifts of direction as might be thought. Shek Kip Mei was the trigger but the ideational and policy drift can be dated back to the pre-war period. 